\title{
THE INJUNCTION IN AID OF LEGAL RIGHTS-AN AUSTRALIAN PERSPECTIVE
}

\author{
The Honourable Mr. Justice William Gummow*
}

INTRODUCTION

It is plain enough that when we speak either in the United States or in Australia of the injunction as an equitable remedy, we do so by reference to the remedy developed in the English High Court of Chancery. But the existence of common origins should not distract attention from the impact upon equitable remedies of the very different systems of government in Britain, the United States, and Australia.

The operation of a federal system of government in the United States and Australia, with the concomitant doctrine of judicial review, has given the injunctive remedy a scope undreamt of by its English creators. Differences between the two federal systems mean that the injunction has some uses in each system it does not have in the other. But, that having been said, what is remarkable is the broad similarity in developments over the last thirty years in the United States and Australia in the "principles" attending the administration of the injunctive remedy in private law. This article shall refer to such matters as the standards for an interlocutory injunction, the adequacy of legal remedies (with the "irreparable injury" rule), and the need for a legal or statutory right of a proprietary nature. In broad terms, the result of these developments is that the injunction is fast losing its character as an extraordinary remedy.

The injunction has been frequently described as a remedy that is discretionary and extraordinary. The former reflects the notion that equitable remedies are designed to meet the needs of the particular case after a close analysis of the facts, and that equitable remedies accommodate the relative merits of plaintiff and defendant in the particular case by, for example, the imposition upon the plaintiff of terms as the price for relief. On the other hand, the description of the injunction as an extraordinary remedy expresses the concern of legal formalism or positivism with judicial discretion. This is an old and continuing conflict. In the terms recently used by Justice Scalia, writing extrajudicially, equity in administering the injunctive remedy is concerned not so much with establishing or applying general rules of law as with a "discretion conferring 
approach." The wide use of the injunction also cuts across the importance traditionally attached to the role of the jury verdict as the paradigm factfinding process, even where there is no constitutional imperative. And, it must not be forgotten that, at least in the Australian experience, the greater the scope allowed judicial discretion at trial, the narrower the avenues of appeal.

It is also important to bear in mind that the fewer rigorous courses in equitable remedies that are available in the law schools, the greater the tendency of the practitioners they produce to engage in the ritualistic repetition of verbal formulae (such as the so-called "irreparable injury rule"). There is also a correlative lack of the necessary confidence (and scholarship), where required, to strip equity back to its basics and reformulate particular doctrines. In a cognate field, the development of the remedial constructive trust has been bedevilled by uncritical repetition of phrases from judgments of Justice Cardozo, a subject that Professor Powell discusses in his article. ${ }^{2}$

As I have indicated, the influence of constitutional law upon the modern development of the injunction in federal systems should not be overlooked. Statutes or executive acts that lack the necessary constitutional support may have a serious impact upon the affairs of citizens even though no property rights are invaded. Yet the injunction is clearly an appropriate remedy. Such considerations have contributed to the loosening, in private law, of the requirements curbing the availability of the injunction. Thus, this article turns first to constitutional law.

\section{II}

\section{CONSTITUTIONAL CONSIDERATIONS}

The federal system of government established by the Australian Constitution is, to a degree, an adaptation of that of the United States. In particular, the judicial power provided for in Chapter III of the Constitution is separated from that of the executive and legislature, and the doctrine of judicial review is entrenched. There are no "legislative courts" (in the United States sense of that term) created by the Parliament outside the provisions of Chapter III. Taxation and bankruptcy matters are adjudicated in the Federal Court of Australia. But military matters do stand in a special position in Australia, as in the United States. ${ }^{3}$

The provisions in the Australian Constitution (sections 75 and 76) specifying the original jurisdiction of the High Court of Australia were drawn from Article III, Section 2, Clause 1 of the United States Constitution. But Article III contained no express provision for injunctive relief against federal officers.

1. Antonin Scalia, The Rule of Law as a Law of Rules, 56 U. CHI. L. REv. 1175, 1177 (1989).

2. H. Jefferson Powell, "Cardozo's Foot": The Chancellor's Conscience and Constructive Trusts, 56 LAW \& CONTEMP. PROBS. 7 (Summer 1993).

3. Re Tracey; ex parte Ryan, (1989) 166 C.L.R. 518, 527, in which the High Court referred to Solorio v. United States, 483 U.S. 435 (1987). 
Accordingly, a provision was added to the Australian Constitution, as section 75(v), to provide for "matters" in which "a writ of Mandamus or prohibition or an injunction is sought against an officer of the Commonwealth ...." Thus, Australia has a constitutionally entrenched federal jurisdiction in public law to use the injunction against officers of the federal government who act or threaten to act, not only pursuant to an invalid law, but also beyond the authority given them by a valid law, in denial of natural justice, or otherwise in error of law. Federal officers have never enjoyed any sovereign immunity of the Commonwealth.

Further, in Australia, there is no equivalent of the Anti-Injunction Act. ${ }^{4}$ Thus, Parliament has not directed the federal courts to refuse any injunction to stay proceedings in a state court. Nor is there any judge-made doctrine of federal abstention, whereby, even though all requirements for jurisdiction and justiciability are satisfied, a court exercising the federal judicial power may not decide some matters before it. The Federal Court of Australia has issued orders against the plaintiff in a proceeding in a state court, where that proceeding was beyond the constitutional competence of the state court or encroached upon the exercise of jurisdiction by the Federal Court. ${ }^{5}$ Such orders have an affinity with the common injunction by which Chancery restrained proceedings in other courts.

The constitutional arrangements in Australia are markedly different in a number of other respects significant in the development of the law of injunctions. First, there is no constitutional guarantee, either at the state or federal level, of trial by jury in civil cases. It is highly unusual for a jury to be used in any civil case arising out of a commercial dispute. Australia has no body of decisions corresponding to that in the United States interpreting the Seventh Amendment. Nor are there, either at the state or federal level, constitutional guarantees of freedom of speech or due process. This is of some significance in the development of the ex parte injunction, or temporary restraining order. Australian courts need not wrestle with the constitutional implications of decisions ${ }^{6}$ concerning wrongs capable of repetition yet evading review, which, although moot because the injury is of limited duration and has ceased before the completion of federal litigation, are treated as justiciable.

The High Court of Australia has exercised with comparative frequency its authority to hold invalid federal legislation that exceeds the powers of the

4. 28 U.S.C. $\$ 2283$ (1978), discussed in ERWIN CHEMERINSKY, FEDERAL JURISDICTION $\$ 11.2$ (1989).

5. St. Justins Properties Pty. Ltd. v. Rule Holdings Pty. Ltd., (1980) 40 F.L.R. 282; Denpro Pty. Ltd. v. Centrepoint Freeholds Pty. Ltd., (1983) 48 A.L.R. 39; Lural Ins. Servs. Pty. Ltd. v. Kairi Pty. Ltd., (1985) Australian Trade Prac. Rep. (CCH) 40-553. See also Grace Bros. Pty. Ltd. v. Magistrates of the Local Courts of New South Wales, (1988) 84 A.L.R. 492, 497, affd, (1989) 23 F.C.R. 68.

6. See, e.g., Carroll v. President and Comm'rs of Princess Anne, 393 U.S. 175 (1968). However, it may be observed that that case involved an ex parte order with effect for no fewer than ten days. In Australia, and therefore quite apart from any constitutional question, I think this would ordinarily be regarded as a miscarriage of judicial discretion. See, CHEMERINSKY, supra note 4, $\$ 2.5 .3$. 
national legislature. The interstate commerce power has never been given the sweep allowed by the Supreme Court of the United States since the aftermath of the New Deal, and other heads of federal power dealing with corporations and family law (which have no counterpart in the powers of the Congress) have, on some occasions, been read rather narrowly. Thus, in the last ten years, provisions of federal laws have been struck down in at least seven cases. ${ }^{7}$ This active use of the doctrine of judicial review gives added scope to the injunctive remedy.

On the other hand, the limited nature of the guarantees found in the Constitution has meant that, in Australia, the occasion has not arisen for the development of the institutional decree, whereby a federal court undertakes the reform of the structure of governmental institutions. Unlike the U.S. courts, the Australian courts have not been called upon to mould decrees having a significant impact upon third parties, such as decrees modifying the conditions of confinement in a prison or mental hospital, changing the manner of voting for public officers, or requiring the levy by a state of an increased property tax to fund the changes in a school system required by the desegregation orders of a federal court. Therefore, there has not been any discussion comparable to that in the United States of the significance for the judicial function of the differences between conventional adjudication of private rights and the new model of institutional remedial litigation. ${ }^{8}$ On the other hand, even in private litigation in Australia, an equity court will take into account the impact of a proposed injunction upon innocent third parties and the public generally. ${ }^{9}$

The position in England stands in marked contrast to those in Australia and the United States. In English public law, the injunction is used to restrain ultra vires or other legally improper conduct of public officers, but, given the absence both of any institutionalised separation of powers and of any doctrine of judicial review of the constitutionality of parliamentary or executive action, the injunction has had no role to play in constitutional law, as we understand it. The English situation has changed only recently and in recognition of the binding force of European Community law given by section 2 of the European Communities Act 1972 (U.K.). In Factortame Ltd. v. Secretary of State for

7. The decisions are Cormick v. Cormick, (1984) 156 C.L.R. 170 (family law); Actors and Announcers Equity Ass'n of Australia v. Fontana Films Pty. Ltd., (1982) 150 C.L.R. 169 (corporations); Queensland Electricity Comm'n v. The Commonwealth, (1985) 159 C.L.R. 192 (State functions); Re F, ex parte F, (1986) 161 C.L.R. 376 (family law); Davis v. The Commonwealth, (1988) 166 C.L.R. 79 (trade marks); The Incorporation Case, (1990) 169 C.L.R. 482 (corporations); Mutual Pools \& Staff Pty. Ltd. v. Commissioner of Taxation, (1992) 66 A.L.J.R. 223 (sales tax).

8. See, e.g., Abram Chayes, The Role of the Judge in Public Law Litigation, 89 HARV. L. REv. 1281 (1976); Frank M. Coffin, The Frontier of Remedies, 67 CAL. L. REV. 983 (1979); Robert E. Easton, The Dual Role of the Structural Injunction, 99 YALE L.J. 1983 (1990). The question of State taxes was considered in Missouri v. Jenkins, 495 U.S. 33 (1990). This case points to the fundamental issue of whether this use of the injunctive remedy may so depart from traditional concepts as to go beyond the constitutional limits of the judicial power.

9. Silktone Pty. Ltd. v. Devreal Capital Pty. Ltd., (1990) 21 N.S.W.L.R. 317, 324. 
Transport (No. 2), ${ }^{10}$ the House of Lords held that the applicants for an interlocutory injunction had a strong case to present to the Court of Justice of the European Communities that British legislation empowering a Minister to make regulations to provide for the registration of British fishing vessels contravened the provisions of the European Treaty by depriving the applicants (who represented Spanish fishing interests) of their Community-law rights. The result was the grant of an interlocutory injunction restraining the Minister from implementing the British law, pending the decision of the European Court. It is perhaps unfortunate that, having regard to the long experience in comparable situations of the federal courts in other English-speaking countries, the House of Lords was content to strike out for itself without any regard for wisdom that might be found elsewhere.

In Australia, the early decisions as to when to grant an interlocutory injunction in aid of a claim of alleged invalidity of a federal statute paid close regard to the experience of the United States. ${ }^{11}$ More recently, Sir Anthony Mason, the present Chief Justice of Australia, said that the principles governing the grant or refusal of interlocutory injunctions in private law litigation are to be applied in public-law cases, including constitutional cases, notwithstanding that different factors arise for consideration. ${ }^{12}$ His Honour referred to the Canadian decision Morgentaler $v$. Ackroyd ${ }^{13}$ where it was suggested that an interim injunction would lie, but only to prevent "grave injustice."14 Of this, Sir Anthony Mason said that it, perhaps, stated the position too strongly against a plaintiff who sought an interlocutory injunction in Australia. His Honour continued:

In arriving at a balance of convenience the Court will take into account the seriousness of the conduct enjoined by the statute and the damage to the public interest that may be caused by restraining its enforcement. And in some cases the balance of convenience may be affected by the Court's perception or evaluation of the strength of the plaintiff's case for invalidity .... In the absence of compelling grounds, it is the duty of the Court to respect, indeed, to

10. [1991] 1 A.C. 603. The decision is discussed by Professor Sir William Wade in two Notes, What Has Happened to the Sovereignty of Parliament?, 107 LAW Q. REV. 1 (1991); Injunctive Relief Against the Crown and Ministers, 107 LAw. Q. REV. 4 (1991). The European Court has since held that the British statutory system was contrary to Community law, as discriminating against nationals of other member states: R. v. Secretary of State for Transport, ex parte Factortame Ltd., [1991] 3 All E.R. 769. See also R. v. Secretary of State for Employment, ex parte Equal Opportunities Comm'n, [1992] 1 All E.R. 545, 561; Kirklees Metropolitan Borough Council v. Wickes Building Supplies, Ltd., [1992] 3 All E.R. 717 (HL).

11. See, e.g., The King v. Macfarlane, ex parte O'Flanagan and O'Kelly, (1923) 32 C.L.R. 518, 529, 539,573 , where reference was made to such decisions as Cruickshank v. Bidwell, 176 U.S. 73, 80-81 (1900), and Boise Artesian Hot and Cold Water Co. v. Boise City, 213 U.S. 276, 282-83 (1909).

12. Castlemaine Tooheys Ltd. v. South Australia, (1986) 161 C.L.R. 148, 153, construed in Richardson v. Forestry Comm'n, (1987) 164 C.L.R. 261; and Polyukhovich v. The Commonwealth, (1990) 64 A.L.J.R. 589.

13. (1983) 42 O.R.2d $659,668$.

14. Cf. Heart of Atlanta Motel v. United States, 85 S. Ct. 1 (1964) (refusing to enjoin enforcement of 1964 Civil Rights Act pending final determination of constitutionality of Act). For reasons that are unclear, this case is not reported in the official United States Reports. 
defer to, the enactment of the legislature until that enactment is adjudged ultra vires. ${ }^{15}$

\section{III}

\section{INTERLOCUTORY INJUNCTIONS}

In Castlemaine Tooheys Ltd. v. South Australia, one of the stated requirements a plaintiff seeking an interlocutory injunction must satisfy was said to be that the plaintiff would suffer "irreparable injury for which damages will not be an adequate compensation unless an injunction is granted."16 In other Australian authorities, reference is from time to time made to the phrase "irreparable injury" in dealing with interlocutory injunction applications. ${ }^{17}$ Speaking of the position in the United States, Professor Laycock has stated that whilst irreparable injury figures prominently in various formulations of the test for preliminary relief, the term is not used in relation to final relief. ${ }^{18}$ That is true also of the Australian authorities. There, the phrase "irreparable injury," when used in relation to applications for interlocutory relief, is understood in the sense explained long ago by Baron Alderson in Attorney-General v. Hallett: "I take the meaning of irreparable injury to be that which, if not prevented by injunction, cannot be afterwards compensated by any decree which the Court can pronounce in the result of a cause." 19 The considerations involved tend, in practice, to merge into those with which the court is concerned in dealing with the balance of convenience.

These points are illustrated by the decision of Chief Justice Mason in Richardson v. Forestry Commission. ${ }^{20}$ The plaintiff, as a federal minister, sought an interlocutory injunction restraining the defendants from carrying on forestry activities in an area in Tasmania, allegedly in contravention of a federal law that sought to give effect to Australia's obligations under the Convention for the Protection of the World Cultural and Natural Heritage. The defendants asserted that the law was invalid. The law provided for a Commission of Inquiry to determine whether the area in question qualified as a "world heritage area." 21 The Chief Justice held that there was a real, as distinct from a bare, possibility that the area did so qualify and that the activities of the defendants might adversely affect its values as a world heritage area. He said that

[d]espite statements that the plaintiff must show that it is probable that the plaintiff will suffer irreparable injury if no injunction is granted, in a case such as the present it is enough for the plaintiff to show that irreparable injury is a

15. Castlemaine, 161 C.L.R. at $155-56$.

16. Id. at 153. The phrase "temporary restraining order" is not used in Australia.

17. See, e.g., infra note 20 and accompanying text.

18. Douglas LayCOCK, THE DEATH OF THE IRREPARABle INJURY RULE 113 (1991).

19. (1847) 153 Eng. Rep. 1316, 1321.

20. (1987) 164 C.L.R. 261.

21. Id. at 264-65. 
possibility in the sense stated. The object of the Act being to preserve intact that which may be a unique heritage, the possibility of injury is enough to sustain an interlocutory injunction by way of protecting the area in question, thereby preserving the subject-matter of the inquiry pending its completion at least. ${ }^{2}$

As a general proposition, in order to secure an interlocutory injunction, the plaintiff must show (1) that there is a serious question to be tried and (2) that the balance of convenience favours the granting of an injunction. The operation of these precepts in practice is best illustrated by a consideration of the following passage from the judgment of Justice McLelland in Kolback Securities Ltd. v. Epoch Mining $N L:^{23}$

Where a plaintiff's entitlement to ultimate relief is uncertain, the Court, in deciding to grant or refuse an interlocutory injunction, must consider what course is best calculated to achieve justice between the parties in the circumstances of the particular case, pending the resolution of the uncertainty, bearing in mind the consequences to the defendant of the grant of an injunction in support of relief to which the plaintiff may ultimately be held not to be entitled, and the consequences to the plaintiff of the refusal of an injunction in support of relief to which the plaintiff may ultimately be held to be entitled .... Where the uncertainty depends in whole or in part on a contested question of fact it is not appropriate for the Court to decide that question on the interlocutory application. Where the uncertainty depends in whole or in part on a contested question of law, it may or may not be appropriate for the Court to decide that question on the interlocutory application, depending on the circumstances, e.g, whether the question is novel or difficult, or is susceptible of resolution on the present state of the evidence, or whether the urgency of the matter renders it impracticable to give proper consideration to the question .... If the Court does decide the question of law the uncertainty is to that extent removed.

Unless the plaintiff shows that there is at least a serious question to be tried which if resolved in its favour would entitle it to final relief, then the requirements of justice as between the parties will dictate that an interlocutory injunction should be refused. ...

Apart from this, although normally the Court "does not undertake a preliminary trial, and give or withhold interlocutory relief upon a forecast as to the ultimate result of the case," . . there are some kinds of case in which for the purpose of seeing where lies the balance of convenience (or more specifically "the balance of the risk of doing an injustice"...), it is desirable for the Court to evaluate the strength of the plaintiff's case for final relief .... One class of case to which this applies is where the decision to grant or refuse an interlocutory injunction will in a practical sense determine the substance of the matter in issue. $^{24}$

The point made by Justice McLelland in the last paragraph reflects the particular concerns that arise where, for all practical purposes, the provisional remedy brings the controversy to an end; a similar approach has been taken in the United States. ${ }^{25}$ As will be apparent from the remarks of Justice

22. Id. at 275 (citing Clements and Marshall Pty. Ltd. v. Field Peas Mktg. Bd. (Tas.), (1947) 76 C.L.R. 401, 407).

23. (1987) 8 N.S.W.L.R. 533, 535-36.

24. Id. (citations omitted).

25. See, e.g., Triebwasser \& Katz v. American Tel. \& Tel. Co., 535 F.2d 1356, 1360 (2d Cir. 1976). 
McLelland, in other respects the position in Australia resembles that advocated by Professor Leubsdorf ${ }^{26}$ and Judge Posner ${ }^{27}$ (the latter with use of an algebraic formula).

In Australia, the Rules of Court of the Federal Court and of the state courts do not spell-out criteria for the grant of preliminary injunctions, such as those found in the United States in Rule 65 of the Federal Rules of Civil Procedure. In Australia, it is a judge-made requirement that the plaintiff be obliged to give to the court what in practice is identified as "the usual undertaking as to damages." In the Federal Court, this is understood as an undertaking to pay to any party adversely affected by the interlocutory injunction such compensation (if any) as the Federal Court thinks just, in such manner as the court directs. It is a matter for the practice of each court to decide whether the undertaking required extends beyond parties to the litigation to third parties. ${ }^{28}$ In the absence of an undertaking, a defendant who has been enjoined but is ultimately victorious at the trial has no recourse to recover the loss suffered in complying with the interlocutory injunction. ${ }^{29}$

In general, the administration of the important remedy of interlocutory injunction is left to the practice as developed by the judges. Thus, in a given case, the court may require that the undertaking be secured. An injunction will be granted ex parte only for a short time, usually no more than one or two days. It is then for the plaintiff to seek continuation of the injunction, as an interlocutory injunction, but with notice having been given to the defendant. The effective operation of the system depends on the existence of a relatively small number of barristers with experience of this type of work. An applicant for an ex parte interim injunction has a duty to disclose to the court all relevant matters, including matters that would have been raised by the other side if the defendant had been present; failure to observe that duty necessitates the discharge of an injunction granted on the application, though a fresh application may be made..$^{30}$

26. John Leubsdorf, The Standards for Preliminary Injunction, 91 HARV. L. REV. 525, 542 (1978).

27. American Hosp. Supply Corp. v. Hospital Prods. Ltd., 780 F.2d 589, 593-94 (7th Cir. 1986).

28. Smith Kline \& French Labs. (Australia) Ltd. v. Secretary, Dept. of Community Servs. and Health, (1989) 89 A.L.R. 366. The appropriate measure of damages is that flowing from the grant of the interlocutory injunction; this must be distinguished from the damages flowing from the litigation-damages not reasonably foreseeable from circumstances known to the plaintiff at the time the interlocutory injunction was obtained will seldom be awarded. Air Express Ltd. v. Ansett Transp. Indus. (Operations) Pty. Ltd., (1979-81) 146 C.L.R. 249.

29. National Australia Bank Ltd. v. Bond Brewing Holdings Ltd., [1991] 1 V.R. 386. In England, the settled practice has been not to require an undertaking as to damages from the Crown where the Crown seeks to enforce a public law, rather than to protect or enforce its proprietary or contractual rights. F. Hoffmann-La Roche \& Co. A.G. v. Secretary of State for Trade and Indus., [1975] A.C. 295; Kirklees Borough Council v. Wickes Building Supplies Ltd., [1991] 4 All E.R. 240. In Australia, an undertaking will be required from the federal government, at least where it seeks an injunction to protect a proprietary rather than a purely governmental right. Commonwealth v. John Fairfax \& Sons Ltd., (1980) 147 C.L.R. 39, 59 (Mason, J.). 540 .

30. Town \& Country Sport Resorts (Holdings) Pty. Ltd. v. Partnership Pac. Ltd., (1988) 20 F.C.R. 
In this as in other areas, there is a tendency to seek comfort in a complex of rules and sub-rules. An example concerns the strength of the case to be shown by an applicant for an interlocutory injunction which is mandatory, rather than prohibitory, in nature. In Shepherd Homes Ltd v. Sandham, Justice Megarry said the following:

[O]n motion, as contrasted with the trial, the court is far more reluctant to grant a mandatory injunction than it would be to grant a comparable prohibitory injunction. In a normal case the court must, inter alia, feel a high degree of assurance that at the trial it will appear that the injunction was rightly granted; and this is a higher standard than is required for a prohibitory injunction. ${ }^{31}$

In a number of Australian decisions, this passage was then described as revealing a "principle" as to the need for a "high degree of assurance in granting temporary restraining orders which were mandatory rather than prohibitory."32 However, the exploration by Professor Leubsdorf, in his important article, ${ }^{33}$ of the development in the last century of the interim injunction showed that the English judicial masters of equity at that time would have eschewed any such rigid formulation. The existence of the alleged principle has now been discounted in the Australian decisions. ${ }^{34}$

\section{IV}

\section{ADEQUACY OF LEGAL REMEDIES}

As is well recognised, where the injunction is sought in aid of purely equitable rights, such as those flowing from a trust or other fiduciary relationship, the question of adequacy of possible legal remedies does not arise. ${ }^{35}$ Thus, it has never been sufficient for a trustee to answer a claim by a beneficiary for an injunction to restrain a breach of trust by allowing that the beneficiary be left to a pecuniary remedy and the breach be allowed to continue. The trust creates equitable, not legal, rights. On the other hand, where the injunction is sought in aid of a legal right, the traditional view has been quite different. In that view, it must be shown, inter alia, that the legal remedy is inadequate. The require-

31. (1971) Ch. $340,351$.

32. For example, Queensland v. Australian Telecommunications Comm'n, (1985) 59 A.L.J.R. 562, 563; Tsimidopoulos v. Mulson Holdings Pty. Ltd., [1989] 1 W.A.R. 359.

33. Leubsdorf, supra note 26, at 525. See also the judgment of Chief Judge Re in United States v. Price, 688 F.2d 204 (3d Cir. 1982), where the point is made that the fact that expenditure of money may be required to comply with an interlocutory mandatory injunction is not necessarily an answer to the making of such an order.

34. See, e.g., Aerospatiale Societe Nationale Industrielle v. Aerospatiale Helicopters Pty. Ltd., (1986) 11 F.C.R. 37; Businessworld Computers Pty. Ltd. v. Australian Telecommunications Comm'n, (1988) 82 A.L.R. 499, 503-04. For English treatment, see Films Rover Int'l Ltd. v. Cannon Film Sales Ltd., [1986] 3 All E.R. 772 .

35. Heavener v. Loomes, (1924) 34 C.L.R. 306, 326. 
ment has been expressed in various ways and has been much discussed in recent literature in the United States. ${ }^{36}$

The requirement was formulated in the eighteenth century when, looking back to the English constitutional struggles of the preceding century and forward to the rise of legal positivism in the next, the Court of Chancery needed to support its decisions against allegations of arbitrary and unprincipled interference in common law proceedings. ${ }^{37}$

In Heavener v. Loomes, two distinguished Australian judges described the position earlier established in England and later carried to Australia as follows:

The foundation of the doctrine of "irreparable damage" is the principle settled by the House of Lords as early as 1773 in Welby v. Duke of Rutland, (1773) 2 Bro. Parl. Cas. 39. The House accepted the argument of the respondent that, where the title sued upon is purely legal, some equity must be shown to justify the intervention of the Court, such as "an injustice irremediable by a Court of law." That is, that the ancillary jurisdiction of the Court could not be invoked in the absence of some special circumstance creating an equity. ${ }^{38}$

James Kent, of the New York Court of Chancery and Justice Joseph Story of the U.S. Supreme Court, who may be taken as the founders of equity jurisprudence in the United States, were, of course, fully apprised of English developments. ${ }^{39}$ Hence, the statement by the United States Supreme Court in 1830, in Boyce's Executors v. Grundy: "It is not enough that there is a remedy at law; it must be plain and adequate, or, in other words, as practical and as efficient to the ends of justice and its prompted administration, as the remedy in equity."

Various reasons could explain why, in a given case, the legal remedy was not as practical and efficient as that in equity. Boyce's Executors v. Grundy, itself, provides an example. It was clear that, in cases of fraud, courts of common law and courts of equity had concurrent jurisdiction. A fraudulent misrepresentation would vitiate the contract. Money paid under it might be recovered, and the fraud could be pleaded in defence to any action brought at law upon the contract. But equity had the means that the common law lacked to ascertain and provide for the adjustments necessary between the parties in cases where a simple handing back of property or repayment of money would not put them in as good a position as before they entered their transaction. Because it thus saw

36. Douglas Laycock, Injunctions and the Irreparable Injury Rule, 57 TEX. L. REV. 1065 (1979) [hereinafter Injunctions] (reviewing OWEN M. FISS, THE CIVIL RIGHTS INJUNCTION (1978)); Douglas Laycock, The Death of the Irreparable Injury Rule, 103 HARV. L. REV. 687 (1990); Peter Linzer, On the Amorality of Contract Remedies-Efficiency, Equity, and the Second Restatement, 81 COLUM. L. REV. 111 (1981); Doug Rendleman, The Inadequate Remedy at Law Prerequisite for an Injunction, 33 U. FLA. L. REV. 346 (1981); Alan Schwartz, The Case for Specific Performance, 89 YALE L.J. 271 (1979); Edward Yorio, In Defense of Money Damages for Breach of Contract, 82 CoLUM. L. REV. 1365 (1982).

37. See David Lieberman, The Province of Legislation Determined: Legal TheORY in EIGHTEENTH CENTURY BRITAIN 71-87, 159-75 (1989).

38. (1925) 34 C.L.R. 306, 325 (Isaacs and Rich, JJ.) (citations omitted).

39. See Peter C. Hoffer, Principled Discretion: Concealment, Conscience, and Chancellors, 3 YALE J.L. \& HUMAN. 53, 61-63 (1991).

40. 28 U.S. (3 Pet.) 210,215 (1830). 
the possibility of restitio in integrum and was able to concede the right of the defrauded party to rescind in a much wider variety of cases than those with which the common law would rescind, the equitable remedy was more practical and efficient to the ends of justice. ${ }^{41}$

Another, and more recent, example of the procedural inadequacies at law that cannot meet the needs of the situation in hand, is provided by Doulton Potteries Ltd. v. Bronotte. ${ }^{42}$ The plaintiff owned a machine of unique design, which was used by it in the manufacture of certain pipes. It sent the die for repair by the defendant, but no price had been fixed between the parties. The defendant later demanded as payment a sum in excess of what the plaintiff regarded as the fair cost of the repairs. The defendant asserted a lien for the sum he claimed. The machine had a special value to the plaintiff because a replacement would take four months to manufacture and the defendant was the only person who could manufacture it. There was then no procedure at law in the New South Wales Supreme Court whereby, if a defendant relied upon a lien, the court might order the property to be given up to the plaintiff, provided he paid into court, to abide by the event of the action, the sum claimed in respect of the lien. It was held that, in those circumstances, the plaintiff was justified in seeking equitable relief, and that the jurisdiction in equity was not limited to cases where the chattel concerned had a peculiar or sentimental value. A declaration was made as to the sum that was a reasonable price for the relevant repairs and, upon an undertaking by the plaintiff to pay that sum, an injunction was granted restraining the defendant from preventing the plaintiff from retrieving the machine in question.

The legal remedy may be inadequate, not for any intrinsic reason, but because of the financial circumstances of the defendant. Thus an injunction may be granted to restrain breach of a pre-receivership contract because a limited chance of recovering upon any verdict for damages exists; this relief has been decreed even though the general body of creditors may thereby be disadvantaged. ${ }^{43}$

Another example of the inadequacy of legal remedies giving rise to an equity is the commission of repeated activities in respect of which the plaintiff would otherwise have to pursue consecutive actions at law. ${ }^{44} \mathrm{~A}$ defendant who evinces an intent not to observe a covenant to pay an annuity to the plaintiff may be required by injunction to observe the covenant, under the sanction of punishment for contempt, rather than leave the plaintiff to resort to an action in debt each year. ${ }^{45}$ Still, the most frequently encountered special circumstance creating an

41. Alati v. Kruger, (1955) 94 C.L.R. 216, 223-24.

42. [1971] 1 N.S.W.L.R. 591.

43. Schering Pty. Ltd. v. Forrest Pharmaceutical Co. Pty. Ltd., [1982] 1 N.S.W.L.R. 286; Re Diesels \& Components Pty. Ltd., (1985) 9 A.C.L.R. 825, 827-28; see also Swiss Bank Corp. v. Lloyds Bank Ltd., [1979] Ch. 548, 566-67; H.C. Horack, Insolvency and Specific Performance, 31 HARV. L. REV. 702 (1918).

44. Angelides v. James Stedman Henderson's Sweets Ltd., (1927) 40 C.L.R. 43, 65-66.

45. Beswick v. Beswick, [1968] A.C. 58, 81, 97-98. For another example, see Developments in the Law: Injunctions, 78 HARV. L. REV. 994, 1001 (1965). Another example is provided by the cases where 
equity for an injunction in aid of a legal right, is the inadequacy of the compensation provided by damages at law.

In his article Injunctions and the Irreparable Injury Rule, Professor Laycock says of the irreparable injury rule:

In the first place, the [irreparable injury] rule has two formulations, and this occasionally causes a judge to think there are two requirements; that there be no adequate remedy at law and that the injury be irreparable. This misunderstanding in turn leads to the suggestion that the injury itself must have some special quality-perhaps that it be especially egregious-when "irreparable injury" should mean simply injury that cannot be repaired (remedied) at law. Thus, even relatively insignificant injury is irreparable if it cannot be measured in money. ${ }^{46}$

The law, as developed in the Australian authorities over a long period, has avoided the misunderstanding referred to by the learned author, and has been expressed in terms consistent with those advocated by him. Thus, the High Court of Australia said, in 1923, that damage would be irreparable in the necessary sense if "pecuniary compensation would be inadequate protection" of the plaintiff's legal right. ${ }^{47}$ Earlier, in the Supreme Court of New South Wales, Sir Phillip Street, the Chief Judge in Equity, had said that, in this context, the word "irreparable" has a special meaning, different from the sense in which it is ordinarily used out of court. Street continued:

What is meant by the term, as I understand it, is simply an injury of so serious a character that damages would not be an adequate compensation, and that on this ground the party should not be compelled to submit to it even for a short period and to take his compensation in the shape of damages. ${ }^{48}$

Contemporary English authority was to like effect. ${ }^{49}$

In the Australian decisions over the last twenty-five years, matters have gone further in favour of extending the availability of the injunction. The point is illustrated by reference to the recent acceptance of the proposition that the court should not ask whether damages would provide the plaintiff with an adequate remedy, but rather whether, in all the circumstances, it is just that the plaintiff should be confined to his remedy in damages. ${ }^{50}$ The beginning of this development may be found in the judgment of Justice Windeyer in the High Court of Australia, in Coulls v. Bagot's Executor and Trustee Company Limited. ${ }^{51}$ His Honour addressed the question of whether specific relief was

repeated trespass to land is enjoined. See, e.g., Whittaker v. Stangvick, 111 N.W. 295, 297 (Minn. 1907).

46. Laycock, Injunctions, supra note 36 , at 1070.

47. The King v. Macfarlane, Ex parte O'Flanagan and O'Kelly, (1923) 32 C.L.R. 518, 550.

48. McCarty v. The Council of the Municipality of North Sydney, (1918) 18 S.R. (N.S.W.) 210, 215.

49. Litchfield-Speer v. Queen Anne's Gate Syndicate (No. 2), Ltd., [1919] 1 Ch. 407, 411.

50. State Transport Authority v. Apex Quarries Ltd., [1988] V.R. 187, 193; City of Melbourne v. Hamas Pty Ltd., (1987) 62 L.G.R.A. 250, 261-262.

51. (1967) 119 C.L.R. 460, 503. 
available to a plaintiff to enforce a contract to pay money or transfer property to a third person who was not a party to the contract and who could not sue on it. Justice Windeyer said:

It seems to me that contracts to pay money or transfer property to a third person are always, or at all events very often, contracts for breach of which damages would be an inadequate remedy -all the more so if it be right (I do not think it is) that damages recoverable by the promisee are only nominal. Nominal or substantial, the question seems to be the same, for when specific relief is given in lieu of damages it is because the remedy, damages, cannot satisfy the demands of justice.

"The Court" said Lord Selborne, "gives specific performance instead of damages only when it can by that means do more perfect and complete justice." 52 Lord Erskine said of the doctrine of specific performance:

This court assumed the jurisdiction upon this single principle; that the party

had a legal right to the performance of the contract; to which right the courts of law, whose jurisdiction did not extend beyond damages, had not the means of giving effect. ${ }^{53}$

Complete and perfect justice to a promisee may well require that a promisor perform his promise to pay money or transfer property to a third party. I see no reason why specific performance should not be had in such cases-but of course not where the promise was to render some personal service. There is no reason today for limiting by particular categories, rather than by general principle, the cases in which orders for specific performance will be made. The days are long past when the common law courts looked with jealousy upon what they thought was a usurpation by the Chancery Court of their jurisdiction. ${ }^{54}$

The English Court of Appeal then spoke in similar terms in Evans Marshall \& Co. Ltd v. Bertola S.A. ${ }^{55}$ In the Supreme Court of Victoria, in Belgrave Nominees Pty. Ltd. v. Barlin-Scott Airconditioning (Aust.) Pty. Ltd., ${ }^{56}$ the plaintiff obtained a mandatory injunction compelling the defendant, a subcontractor for the renovation of buildings owned by the plaintiffs, to deliver up a certain air conditioning plant that had been affixed to the premises and that had been wrongly removed by the defendant. The Victorian Supreme Court had particular regard to the pecuniary circumstances of the plaintiffs and to the closeness to completion of the renovations; it concluded that, in all the circumstances, it would not be just to confine the plaintiffs to their remedy in damages for detention, conversion, and trespass. ${ }^{57}$

The result of these developments is that little is now heard in Australian courts of any "rule" as to the need for "irreparable injury." In addition, although the injunction is, as I have indicated, a remedy in Australian constitutional law, its use there has not been attended with the controversy sometimes apparent in the United States, particularly in civil rights litigation.

52. Wilson v. Northampton and Banbury Junction Ry. Co., (1874) 9 Ch. App. 279, 284.

53. Alley v. Deschamps, (1806) 33 Eng. Rep. 278, 279.

54. (1967) 119 C.L.R. at 503.

55. (1973) 1 W.L.R. 349, 379-80

56. (1984) V.R. 947.

57. Id. at 955 . 
There has not been any call to lessen the role of the injunction in constitutional law by reviving and strengthening an "irreparable injury" rule.

Nevertheless, from time to time, cases do arise in private law where a plaintiff fails to obtain specific relief, not because of any element of personal service or other special relationship between the parties, or because of alleged difficulty of the supervision of any mandatory orders, but on the footing that damages will provide an adequate recompense. I shall discuss two lines of authority.

In The South African Territories Limited v. Wallington, Lord Macnaghten presented the traditional view that specific performance of a contract to lend money cannot be enforced is so well established, and obviously so wholesome a rule, that it would be idle to say a word about it. ${ }^{58}$ Professor Laycock refers $^{59}$ to the recent refusal of the district court, in City Centre One Associates v. Teachers Insurance \& Annuity Association, ${ }^{60}$ to enforce, at the suit of the lender, a moneylending contract where the expected return from the lender over thirty-five years included a share of the profits in an office block in Salt Lake City to be constructed with the money in question. Plainly, such long-term profits would be difficult to measure. Nor was the contract simply one to lend and repay money at interest.

In a somewhat similar vein is the decision of the Privy Council, in Loan Investment Corporation of Australasia v. Bonner. ${ }^{61}$ The respondent wrongly repudiated an agreement to sell land and lend money to the appellant. The appellant unsuccessfully contended for an order for specific performance of the agreement, and was left to seek damages. The contract confirmed a sale and purchase of land for $£ 13,300$ and the lending and borrowing of $£ 11,000$ without security for ten years at $7.5 \%$ interest. ${ }^{2}$ The majority of their Lordships held that where a composite contract includes what was a long-term, unsecured loan, the loan ought not to be treated as something different simply by being connected with a sale of land. ${ }^{63}$ The dissenting member of the Board was the Chief Justice of Australia, Sir Garfield Barwick. He said:

No doubt the general assumption is that damages for a breach of a mere promise to lend money adequately compensates the would be borrower. But, in my opinion, that assumption of fact is not necessarily of universal validity and, again in my opinion, must yield in any case when in fact in the particular circumstances damages would not do justice between the parties. So it seems to me that equity in the more complicated conditions of the modern world may well yet find an occasion when justice can only be done in relation to a contract merely to lend money by ordering its specific performance. But whatever the position as to a promise which is no more than a promise to lend money, I can see no reason in principle why the presence of a term in a contract that money

58. [1898] A.C. $309,318$.

59. LAYCOCK, supra note 18 , at 102.

60. 656 F. Supp. 658 (D. Utah 1987).

61. [1970] N.Z.L.R. 724.

62. Id. at 734 .

63. Id. at 735 . 


\begin{abstract}
shall be advanced itself calls for a denial of the remedy of specific performance. Still less can I see any departure from principle in ordering specific performance of a contract to sell or purchase land where one term of the purchase is that money shall be left in the hands of one of the parties to be payable to the other on the basis of money lent rather than as a balance of purchase money. There is, as I have said, no difficulty whatever in ordering specific performance of an obligation to pay money ....

If the agreement is performed the appellant will have the land which in general is an appreciating asset certainly in places such as New Zealand (as to which possibility there was positive evidence in the case) against a very small outlay of cash, [and] have a lengthy time in which to pay what was, in my opinion, in substance the balance of the purchase price. ... But the dominant reason for holding that damages cannot be a sufficient remedy is that the subject-matter of the agreement was in whole or in part the transfer of land. ${ }^{64}$
\end{abstract}

The current position in Australia is best illustrated by Wight v. Haberdan Pty $L t d .^{65}$ After noting that the general rule was not founded upon any philosophical objection to an order entailing the mere payment of money, Justice Kearney said that the question to be determined was whether damages would be adequate to answer the demands of justice. In the present case, as in Vandeventer v. Dale Construction Co. ${ }^{66}$ to which his Honour referred, the complications involved in the plaintiff being left to pursue a claim for damages were so monumental, and the prospects of an adequate recovery so remote, as to render such a course an unjust imposition on the plaintiff. The plaintiff obtained specific performance of a contract with a moneylender to provide accommodation to enable completion of a contract to purchase land for development. The plaintiff had been induced by the moneylender to enter into the project, had mortgaged other assets to it, and would, as a practical matter, be unable to refinance elsewhere to complete the purchase, as time was of the essence.

Cases dealing with trespass to land also require special mention. It is wellsettled that an action lies at law for trespass to land and nominal damages are recoverable without proof of actual damage. As I have indicated, an injunction may issue to restrain repeated trespasses, so as to avoid a multiplicity of actions at law for nominal damages. But such cases apart, the traditional view has been that a court may refuse to issue an injunction where the plaintiff suffers no appreciable damage, and the plaintiff is left to the dry action at law. However, in Woollerton and Wilson Ltd v. Richard Costain Ltd., ${ }^{67}$ Justice Stamp said that "the very fact that no harm is done is a reason for rather than against the granting of an injunction" in a trespass case. That is a non sequitur. Further, in John Trenberth Ltd $v$. National Westminster Bank Ltd., ${ }^{68}$ Justice Walton supported the grant of an injunction to restrain a trespass on the odd ground that

64. Id. at 742,744 .

65. [1984] 2 N.S.W.L.R. 280.

66. 534 P.2d 183 (Or. 1975).

67. [1970] 1 All E.R. 483, 485.

68. (1979) 39 P. \& C.R. 104, 108. 
such an order was "very close" to an order enforcing a contractual negative stipulation. These authorities, curious though they are, were accepted by the Court of Appeal in Patel v. W.H. Smith (Eziot) Ltd. ${ }^{69}$

\section{$\mathrm{V}$ \\ A LEGAL RIGHT}

It appears clear enough that a plaintiff cannot obtain an injunction in aid of what otherwise has no identifiable existence as a constitutional or a statutory right, or a right arising under the general law of contract and tort. Thus, both English and Australian courts hold that a plaintiff is not entitled to an injunction to restrain activity calculated to cause damage to the business and goodwill of the plaintiff, where the defendant's activity, although injurious, is not tortious. ${ }^{70}$

Equity may restrain a party from commencing or pursuing legal proceedings in a foreign forum. Such cases are not decided merely by asking whether the plaintiff has an adequate remedy in damages in the local forum for the tort of malicious prosecution arising from the foreign proceedings. It is said that the local court has a duty to protect its jurisdiction to the extent necessary to provide full justice to litigants and to give effect to the public policies of the forum. ${ }^{71}$ Again, there is an affinity with the common injunction of former times. In Australia, this is a jurisdiction with a substantial history, one that still flourishes. $^{72}$ But what is the legal right of the plaintiff who seeks an injunction against the institution or continuation of proceedings in the foreign court? In an English decision, Associated Newspapers Group plc v. Insert Media Limited, ${ }^{73}$ Justice Hoffman said that the plaintiff in the forum does not seek to assert any independent cause of action but, rather, "a right not to be sued in the foreign court." In other cases, the "right" of the plaintiff may be an immunity from interference by unconstitutional laws or executive action, and in such a case, the "right" flows from the terms of the Constitution itself. ${ }^{74}$

\section{VI \\ LEgal Right OF A PROPRIETARY NATURE}

There were many statements in nineteenth century English cases to the effect that the foundation of equitable interference by injunction was the protection of

69. [1987] 2 All E.R. 569, 573.

70. White v. Mellin, [1895] A.C. 154; Moorgate Tobacco Co. Ltd. v. Philip Morris Ltd. (No. 2), (1984) 156 C.L.R. 414; Associated Newspapers Group v. Insert Media Ltd., [1988] 2 All E.R. 420; Williams v. Marac Australia Ltd., (1986) 5 N.S.W.L.R. 529, 532-33.

71. Laker Airways v. Sabena, Belgian World Airlines 731 F.2d 909 (D.C. Cir. 1984). See EDWARD D. RE, CASES AND MATERIALS ON REMEDIES ch. 3, $\$ 3$ (2d ed., 1987).

72. Morgan v. Higginson, (1897) 13 W.N. (N.S.W.) 146, 200; National Mutual Holdings Pty. Ltd. v. Sentry Corporation, (1989) 22 F.C.R. 209, 230-233; Re Siromath Pty. Ltd. (No. 3), (1991) 9 A.C.L.C. 1587. The same is true of Canada. See Amchem Products Inc. v. Workers' Compensation Board, (1990) 75 D.L.R. (4th) 1.

73. [1988] 2 All E.R. 420, 424-25.

74. Tableland Peanuts Pty. Ltd. v. The Peanut Marketing Board, (1984) 58 A.L.J.R. 283, 284. 
property. In Australia, those pronouncements struck what once seemed to be a deep root. So it was that, in 1934, in refusing an application for an injunction to restrain the expulsion of the plaintiff from a major national political party, the High Court said, in Cameron v. Hogan, "The foundation of the jurisdiction to grant an injunction is the existence of some civil right of a proprietary nature proper to be protected." 75 Three years later, the High Court rejected the notion, then current in England, that a person who paid an admission fee to enter upon premises to view a spectacle or entertainment thereby acquired an interest sufficiently proprietary in character to merit protection by injunction against wrongful removal from the premises. ${ }^{76}$

Yet, in the more recent Australian decisions, there is little to be seen of the principle propounded in Cameron v. Hogan. Nor have cases been reported in which plaintiffs with a legal right are denied injunctive relief on the footing that the legal right is not proprietary in nature. It is instructive to trace the development of the authorities to this condition. A similar situation appears to have been obtained in the United States, at least since Kenyon v. City of Chicopee $^{77}$ was decided in Massachusetts in 1946, wherein the court held that equity protects personal rights by injunction upon the same condition as it protects property rights.

The law as to the granting of injunctive relief in aid of negative covenants has long been in a special position. Lord Cairns L.C. said, in Doherty v. Allman, ${ }^{78}$ that in enforcing a negative covenant, equity had no discretion to exercise. From time to time, his Lordship's remarks were interpreted as significant in two respects: first, that no question of the adequacy or inadequacy of damages arose; and second, that the plaintiff did not have to demonstrate any proprietary right. However, in more recent times, the Lord Chancellor's remarks have been interpreted as meaning, perhaps, no more than that where a party comes to court to oppose the grant of such an injunction, on the footing that hardship would be caused by the grant of the injunction, equity says "[w]hy should it be a hardship that you be made to keep your promise?"79 Further, in Dalgety Wine Estates Proprietary Limited v. Rizzon, ${ }^{80}$ Justice Mason said that there had been general disagreement as to how the statement by Lord Cairns should be reformed if it were accurately to express the true principle. His Honour continued:

75. (1934) 51 C.L.R. 358, 377 (Rich, Dixon, Evatt, McTiernan, JJ.). There were similar statements in U.S. authorities. See Developments in the Law, supra note 45, at 998-1001.

76. Cowell v. The Rosehill Racecourse Co. Ltd., (1937) 56 C.L.R. 605. The High Court there refused to follow the decision of the English Court of Appeal in Hurst v. Picture Theatres Ltd., (1915) 1 K.B. 1. Justice Dixon referred with approval to the decision, delivered by Justice Holmes, in Marrone v. Washington Jockey Club, 227 U.S. 633 (1913). Marrone was recently reaffirmed as authoritative by the Maryland Court of Appeal in Silbert v. Ramsey, 482 A.2d 147, 150-51 (1984).

77. 70 N.E.2d 241, 244 (Mass. 1946). See Donald E. Eames, The Protection of Personal Rights In Equity Since 1946, 32 B.U.L. REV. 419 (1952).

78. (1878) 3 App. Cas. 709, 719-20, construed in WALTER ASHBURNER, PRINCIPLES OF EQUITY $384-$ 85 (Davis Browne ed., 2d ed. 1933).

79. Pullen v. Abalchek Pty. Ltd., (1990) 20 N.S.W.L.R. 732, 735.

80. (1979) 141 C.L.R. 552. 
The reason for this is that it is quite impossible to formulate an illuminating statement of principle which is capable of universal application. There is no limit to the number and to the kind of negative stipulations, express or implied, which the courts may be asked to enforce. It is not surprising, therefore, that it has emerged from a long line of judicial decisions that the attitudes of the courts to the enforcement of negative stipulations have varied according to the nature of the stipulation, the nature of the contract in which it is found, the effect which enforcement will have on the relationship of the parties under the contract and the character of the order required to enforce the stipulation.

Thus, the courts have frequently refused injunctions to restrain a breach of a negative stipulation in a contract for the sale of chattels or goods, in a contract for personal service and in a contract the enforcement of which would require the contractor to supervise the performance of the contract .... [T] hese instances clearly demonstrate that the courts have a general discretion to refuse relief by way of injunction, even in cases where the court's consideration does not extend beyond the private rights of the parties to a contract . . ${ }^{81}$

The requirement of a proprietary interest has been used to support the denial of injunctive relief against the commission of torts that do not injure the proprietary rights or interests of the plaintiff. An example is trespass to the person, although, as has been pointed out, trespass also may be a crime. ${ }^{82}$ However, paragraph 114(1)(a) of the Family Law Act of 1975 invests the Family Court of Australia with jurisdiction to grant an injunction for the personal protection of a party to a marriage or to a child of the marriage. ${ }^{83}$

It also has been said that an injunction does not lie to prevent publication of a libel or slander unless the plaintiff can show that the apprehended wrong also would amount to the commission of the tort of trade libel or malicious falsehood, injuring the plaintiff's commercial interests. ${ }^{84}$ In defamation cases, the Australian courts have held that the plaintiff cannot obtain injunctive relief without establishing that a subsequent finding by a jury that the matter complained of was not defamatory of the plaintiff would be set aside as unreasonable, and that there is no real ground for supposing that the defendant might succeed upon any defence of justification, privilege, or comment. ${ }^{85}$

But the plaintiff's lack of a proprietary right in his or her reputation was not the only basis of denial of equitable relief. Quite apart from any constitutional guarantee, Fox's Libel Act 1792 marked the end, in Britain, of a long parliamentary struggle to ensure that cases of libel would be tried at common law, before a jury. Why, then, should an equity judge preempt that issue? In Fleming $v$. Newton, ${ }^{86}$ Lord Cottenham L.C., in the course of dealing with an appeal from

81. Id. at 573-74.

82. Corvisy v. Corvisy, [1982] 2 N.S.W.L.R. 557, 561.

83. Family Law Act 1975 (Cth).

84. Swimsure (Laboratories) Pty. Ltd. v. McDonald, [1979] 2 N.S.W.L.R. 796, 799; see also Kenyon, 70 N.E.2d at 244.

85. Stocker v. McElhinney (No. 2), [1961] N.S.W.R. 1043, 1048. See also Robert A. Hayes, Injunctions Before Judgment in Cases of Defamation, 45 A.L.J. 125, 181 (1971). There is, as I have indicated, no constitutional impediment to "prior restraint."

86. (1848) 9 Eng. Rep. 797, 803. 
Scotland, said:

That act [55 Geo. III cap. 42] appoints a jury as the proper tribunal for trial of injuries to the person by libel or defamation; and the liberty of the press consists in the unrestricted right of publishing, subject to the responsibilities attached to the publication of libels, public or private. But if the publication is to be anticipated and prevented by the intervention of the Court of Session, the jurisdiction over libels is taken from the jury, and the right of unrestricted publication is destroyed. ${ }^{87}$

Whilst asserting the existence of the jurisdiction in equity, Roscoe Pound said that "it must be admitted that Lord Cottenham put his finger on a serious difficulty in the way of injunctions in these cases." ${ }^{88} \mathrm{He}$ also pointed out ${ }^{89}$ that equity is not precluded from preventing irreparable injury through a civil wrong because the act, in another aspect, may be the subject of a criminal prosecution.

Statutory law has also had an important part to play in the decline of the significance attached to the requirement of a proprietary right. A particular statute may both create new rights and provide, in terms, for enforcement by injunction. Laws establishing the patent and copyright systems are obvious examples. Further, the statute may specify that the injunctive remedy is available, but with variations to what would otherwise be the requirements under the general law. An example is section 80 of the Trade Practices Act 1974, ${ }^{90}$ which invests the Federal Court of Australia with the power to enjoin contraventions both of the antitrust provisions and of certain consumer protection provisions of that legislation. As amended in 1977, section 80 empowers the court to grant an interim or a final injunction, whether or not the defendant has previously engaged in the conduct in question, and whether or not there is "an imminent danger of substantial damage to any person" if the defendant engages in the conduct. ${ }^{91}$

Other statutes create new rights in specified classes of persons and provide for new remedies, but do not specifically include among them the injunction. In such cases, the general rule is that specified by Justice Farwell in Stevens v. Chown:

In my opinion there was nothing to prevent the old Court of Chancery from granting an injunction to restrain the infringement of a newly created statutory right, unless the Act of Parliament creating the right provided a remedy which if enacted should be the only remedy-subject only to this, that the right so created was such a right as the court under its original jurisdiction take cognizance of. ${ }^{92}$

87. Id.

88. Roscoe Pound, Equitable Relief against Defamation and Injuries to Personality, 29 HARV. L. REv. 640, 657 (1915-1916).

89. Id. at 643 .

90. Trade Practices Act 1974 (Cth).

91. Id. \& 80 .

92. [1901] 1 Ch. 894, 904. 
In many of the cases dealing with new rights created by statute, an attenuated meaning has been given to the concept of proprietary right. Two examples will suffice. In Howes v. Gosford Shire Council, ${ }^{93}$ Justice Jacobs granted an injunction against the servants and agents of the defendant local government authority, and against four of its councillors, which restrained them from acting on a resolution purporting to dismiss the plaintiff. The ground for intervention was that the resolution was void for want of a quorum at the meeting. The plaintiff held office as the Shire Clerk under a contract of service and under the provisions of a state statute regulating local government. Justice Jacobs said that the interest of the plaintiff was not that arising from the mere relation of master and servant (in which case equity had no jurisdiction to interfere), but from the interest of the plaintiff arising from his statutory office. ${ }^{94}$ The latter was all that was required to establish his right to protection by injunction.

The legislation with which the Supreme Court was concerned in Potter $v$. Ferguson ${ }^{95}$ imposed a duty on a landlord to give to a tenant a right in the nature of a right of preemption or first refusal, that is to say, an obligation requiring the landlord to refrain from selling without giving to the tenant the opportunity of purchasing in preference to any other buyer. Justice Powell held that, although the statute thereby created no equitable interest in the subject land, the tenant had a personal right enforceable by injunction. ${ }^{96}$

In other cases, the injunction is granted in aid of the new statutory right without any enquiry as to whether or not the right is proprietary in nature. An example is provided by Bradley $v$. The Commonwealth. ${ }^{97}$ There, the High Court granted an injunction to restrain interference by the federal government with the plaintiff's right to use postal and telephonic services conferred by the Post and Telegraph Act of 1901. The plaintiff had been using these services to conduct the "Rhodesia Information Centre"; the federal government was antipathetic to the giving of support to the regime then in power in what is now Zimbabwe.

Difficulties have arisen also in cases where the court has been dealing not with legislation creating rights in the plaintiff, but with prohibitions imposed by statutes of general application, so that the complaint is of the violation by the defendant of a public right. A number of cases have been concerned with repeated infractions of municipal laws imposing a restriction or prohibition upon the use of land. In Attorney-General v. Gill, ${ }^{98}$ decided in 1926, a distinction was drawn between statutory prohibitions creating public rights of a proprietary nature (for example, statutes forbidding the obstruction of highways) and

\footnotetext{
93. [1962] N.S.W.R. 58.

94. Id. at 65 .

95. [1979] 1 N.S.W.L.R. 364.

96. Id. at 373.

97. (1973) 128 C.L.R. 557.

98. [1927] V.L.R. 22.
} 
statutory prohibitions not doing so (for example, statutory prohibitions restricting the use of land in residential districts). Only the former attracted the equitable jurisdiction to interfere by injunction.

However, in later decisions, courts recognised that the notion of publicly held proprietary rights was confused and impractical. Many injunctions were granted to protect benefits or advantages that could not be regarded as having any resemblance at all to proprietary rights. Finally, in 1963, the High Court granted injunctive relief in aid of a restraint upon the engagement in trade or business in a residential area, and said that the wide discretion of the court was an adequate safeguard against abuse of the salutary procedure available by injunction. ${ }^{99}$

The appropriate plaintiff, where the court is enforcing by injunctions prohibitions imposed by statutes of general application, is the Attorney-General, acting with or without a relator. A further complication arises where the Attorney-General of the day declines to seek an injunction to enforce such a statutory prohibition or to lend his name to such proceedings, but private citizens assert the necessary standing to act in his place. In many such cases, the statute in question has been concerned with prevention of public nuisances, and the plaintiff has asserted a peculiar injury from the nuisance to the plaintiff's proprietary rights. In those cases, the plaintiff clearly has had standing. The difficulty that has arisen has occurred where the plaintiff's interest in the matter derives otherwise than from an apprehended injury to proprietary rights.

The Australian authorities indicate that an equity court will lend its aid to the enforcement of a statute at the suit of a person who has a "special interest" in its enforcement, being an "interest" over and above that held by the ordinary members of the public, and being more than a "mere intellectual or emotional concern" in the subject matter. ${ }^{100}$ It is clear from the authorities that the "interest" need not be a proprietary interest, let alone a legal interest. Thus, in Onus v. Alcoa of Australia Limited, ${ }^{101}$ persons who claimed to be descendants and members of a particular Aboriginal tribe, and to be custodians of relics of cultural and spiritual importance to those people, were held to have standing to commence an action to restrain a corporation from contravention of the prohibition in section 21 of the Archaeological and Aboriginal Relics Preservation Act of $1972 .^{102}$

In the result, there is now much to be said for the proposition that, in Australia, an injunction lies to protect legal rights, only if those rights may be described as proprietary in character. In describing rights as proprietary in character, the courts have been apt to use circular reasoning. Speaking of

99. Cooney v. The Council of Ku-ring-gai, (1963) 114 C.L.R. 582, where the earlier authorities are collected and discussed.

100. Australian Conservation Foundation Incorporated v. The Commonwealth, (1980) 146 C.L.R. 493.

101. (1981) 149 C.L.R. 27.

102. (Vict.). 
common law trademarks, Justice Windeyer said the following:

There is, no doubt, some circuity in saying that the protection which the Court of Chancery gave by injunctions to plaintiffs who had acquired trade marks by use and reputation made such trade marks a form of property-and then saying that the intervention of the Court in such cases was based upon the protection of an equitable proprietary interest. ${ }^{103}$

It is true also in this field that, as with the inadequacy of damages, in many cases other reasons might have been found for the denial of injunctive relief. With the erosion of dogmatically stated principles, it is now appropriate to deal, in terms, with those other reasons when they are seen to be of decisive importance.

\section{VII}

\section{CONCLUSION}

The Australian experience confirms what was said, under the heading "The Triumph of Equity" by Professor Chayes in his article The Role of the Judge In Public Law Litigation:

One of the most striking procedural developments of this century is the increasing importance of equitable relief. It is perhaps too soon to reverse the traditional maxim to read that money damages will be awarded only when no suitable form of specific relief can be devised. But surely, the old sense of equitable remedies as "extraordinary" has faded. ${ }^{104}$

103. Colbeam Palmer Ltd. v. Stock Affiliates Pty. Ltd., (1968) 122 C.L.R. 25, 34. See also Felix S. Cohen, Transcendental Nonsense and the Functional Approach, 35 COL. L. REV. 809, 814-17 (1935).

104. Chayes, supra note 8 , at 1292. 